Research, part of a Special Feature on Public policies and management of rural forests: lasting alliance or fool's dialogue?

\title{
Social-ecological Functions and Vulnerability Framework to Analyze Forest Policy Reforms
}

\author{
Fanny Rives $^{1}$, Martine Antona $^{1}$ and Sigrid Aubert $^{2}$
}

\begin{abstract}
We explore the impact of forest policy reforms implemented in the early 1990s in Niger in the wake of the severe droughts that affected the Sahel in the 1970s and 1980s. We focus on Sahelian multiple-use forest ecosystems and set out to analyze policy-induced changes in the patterns of interactions between various uses, users, and dry-forest ecosystems, interactions that influence the effective management of rural forests. We put forward the hypothesis that the new forest policy reforms were designed according to a vulnerability diagnosis, highlighting two stressors: droughts and increased demand for firewood. This led to a single-issue policy focused on firewood provision and was implemented through the Household Energy Strategy (HES). The HES established new local management schemes for "rural forests" through "rural firewood markets" (RMs) to regulate firewood harvesting and trade. We studied one of the first rural forests to become an RM in Niger in 1993. We used the concept of social-ecological functions as processes emerging from the interactions between social and ecological systems (SES). We identified sixteen SES functions and specifically analyzed the changes in three of them, whether they were targeted by the policy reform (firewood provision) or not (gum provision and livestock production). The changes generated by the creation of the RM have had different impacts on SES functions, as well as on the social and ecological components that contribute to these functions, because of their interaction with firewood provision. Mutual benefits and competitions between SES functions have been identified. The analysis of mutual benefits and competitions reflects the ambiguous role of the policy reform on rural forest ecosystems in Niger. Our results show that the patterns of interactions between key SES functions have played a more important role in the SES trajectory than any single resource such as timber or firewood. This provides insight into strengthening potential feedback between rural forest functions for improved resilience and livelihoods.
\end{abstract}

Key Words: ecosystem services; fuelwood; rural forest; Sahel; social-ecological changes; socio-ecological changes

\section{INTRODUCTION}

The devolution of authority for forest management from the State to rural stakeholders emerged in forest policies in the 1990s (Buttoud 2001, Larson 2005, Montagne and Bertrand 2006). These policies reveal a new trend in forest management where the role of rural stakeholders and the multiple uses of forests are recognized (Babin and Bertrand 1998, Aubert 2003, Nelson 2010).

In Niger, such policies were developed through the Household Energy Strategy (HES) in the 1990s, following the severe droughts that affected the Sahel. The policies were based on studies of expected changes. In a context of increased demand for firewood in urban areas, forest experts reported on forest degradation and the risk of firewood shortages for supplies to urban households (Bertrand 1985, World Bank and United Nations Development Programme 1989, Foley et al. 1997, Ribot 1999b). The HES was designed to respond to this issue by giving the responsibility for forest management to rural people through the concept of "rural firewood markets" (RMs). The establishment of RMs led to the identification of "rural forests" as new territories managed by rural populations, which became a source of benefits and income for them.

Niger's experiment inspired many African countries, such as Chad, Madagascar, and Mali, to design their own forestry and energy policies. Several studies were conducted to analyze these policies, their implementation, and their effects on effective forest management. The studies focused either on the emergence of the policies (Benjaminsen 1997, Bertrand and Montagne 2006), or on their implementation and the way the new forest management rules were defined and enforced (Chomitz and Griffiths 1997, Antona and Bertrand 2006, Rives et al. 2012), or on the changes they induced in power relationships between stakeholders (Ribot 1999a, Hautdidier 2008, Gautier et al. 2011).

A more global approach for understanding how such policies influence effective management in rural forests is lacking. Policy reforms stem from the identification of a problem. The identified problem and understanding of its roots are linked to a cognitive representation of reality (Kingdon 2003). Although policy strategies depend on the specific representation that their designers have of the problem, they are implemented in a real and obviously more complex world. Rural forests in Niger are characterized by multiple user interactions influencing various resources (Raynaut et al. 1997, Petit 2000). In such a context, in order to analyze forest policy reforms, it is necessary to understand (1) on which representation of which forest degradation issue the reforms were based, (2) which policy instruments were thus developed, 
and (3) what the consequences of those reforms are for rural forest uses. Focusing on interactions between ecological and social dynamics is highly relevant in Sahelian rural forests because rural people in drylands depend directly on ecological production. The need for frameworks focusing on such interactions is highlighted by several scholars (Berkes and Folke 1998b, Haberl et al. 2006, Ostrom 2009, Collins et al. 2011).

We hypothesize that forest management devolution policies in Niger are based on a representation of the causes of forest degradation that is tantamount to a vulnerability diagnosis. We show how the way a policy is built will define its actions. To analyze the effects on rural forests, we studied the changes in the Ninpelima rural forest, where the HES has been implemented since 1993. We use the concept of socialecological system (SES) and introduce social-ecological functions (SES functions) as the analytical unit to assess changes in SES. We show that the Household Energy Strategy targeted a specific SES by focusing on one specific socialecological function: firewood provision. However, it induced changes in other SES functions. We describe more precisely the changes in two SES functions, gum provision and livestock production, to show how the HES affected interactions between functions.

The first section of the paper provides insight into the representations underpinning the HES, and the second section presents our analysis of HES effects in the specific case of the Ninpelima RM.

\section{REVEALING THE REPRESENTATIONS UNDERLYING THE HOUSEHOLD ENERGY STRATEGY}

Public policies are framed by different factors: a representation of reality and of the issue they are intended to cope with, in addition to a path dependency to former policy schemes and identified interest groups looking for compromises through specific policies (Sabatier 2007, Tacconi 2007, Béné et al. 2009, Fernandez et al. 2011).

To analyze the effects of the HES on forest management in Niger, we needed to go beyond a mere description of the policy reforms and understand the diagnosis of the causes of forest degradation that underlie the HES, HES solutions, and expected effects.

\section{Using a vulnerability approach to analyze the Household Energy Strategy}

We used various data sources to grasp the representations and strategies underpinning the HES. Firstly, we analyzed Household Energy Project implementation and progress reports drafted by experts:

- two reports submitted prior to, and at the beginning of this project (Madon and Matly 1986, Groupement SeedCTFT 1994);
- a report published by the World Bank that describes the project background, the project itself, and its implementation (Foley et al. 1997); and

- an edited book that gives an overview of discussions on the HES (D'Herbès et al. 1997).

Secondly, interviews were conducted with institutional actors involved in the HES: an official from the Ministry of Forestry, a lawyer, two forest experts, two forest civil servants from the rural council of Torodi, and a representative of the trade association of Niamey wood traders.

The arguments justifying the HES in the interviews and the various documents were analyzed using the vulnerability framework of Turner II et al. (2003). These authors define vulnerability as "the degree to which a system, subsystem, or system component is likely to experience harm due to exposure to a hazard, either a perturbation or stress/stressor." Vulnerability is conceptualized as being constituted by exposure, sensitivity, and adaptive capacity to perturbations/ stressors (Gallopín 2006, Miller et al. 2010). Exposure is the nature and degree to which the system is in contact with perturbations. Sensitivity is the degree to which a system is modified or affected by perturbations. Adaptive capacity is the ability of a system to evolve in order to accommodate perturbations (Adger 2006). Social and ecological conditions determine the sensitivity of the system to some perturbations, and influence its adaptive capacity (Turner II et al. 2003).

This vulnerability approach challenges the previous approaches of impact analysis. Instead of focusing on the impacts of the perturbation, it seeks to understand the internal conditions that make the system vulnerable to the perturbation (Turner II et al. 2003).

\section{Household Energy Strategy history, justification, and implementation}

The HES analysis on the causes of forest degradation was influenced by international policies on natural resource management in the 1990s, past experience of forest policies in Niger, and two severe Sahelian droughts. The diagnosis prior to the HES determined the policy choices for dealing with the problem. The contextual elements, the diagnosis, and the policy instruments suggested by the HES are presented in the following sections.

\section{Context of Household Energy Strategy emergence}

Up to the 1990s, the laws and rules on forest management and firewood harvesting in Niger originated from the colonial legacy (Foley et al. 1997, Ribot 2001). The 1974 forest law maintained the principle of appropriation of forest land by the State (République du Niger 1974), considered as the only entity with the capacity to manage and restore forests and to protect them from overuse (Elbow and Rochegude 1990). Rural people were entitled to have use rights on forest resources but had no rights to market wood resources (Ribot 
2001). Firewood harvesting was regulated by permits allocated by the Forest Department to traders (Elbow and Rochegude 1990). Firewood was harvested by urban traders from Niamey who hired mainly woodcutters from the cities (Mamoudou 1991). Only a few rural stakeholders worked for the traders, and little income was generated from firewood provision on a rural scale.

The HES emerged in the context of two severe droughts that affected the Sahel in 1973 and 1984 (Foley et al. 1997). These events raised international concern about advancing desertification in the Sahel (Foley et al. 1997, Raynaut 2001) and the migration of rural people to urban areas. The fear of firewood shortages in the Sahel is ancient (Ribot 1999b), and it was awakened by these droughts. Consequently, international organizations developed scenarios of firewood supply and demand, and reached alarmist conclusions on the "fuelwood gap" (World Bank and United Nations Development Programme 1989).

The international context was also in favor of such reform. On the eve of the 1992 Rio Conference on Environment and Development, the trend was to recognize the role of rural stakeholders in forest management and to promote the decentralization of natural resource management. The HES was launched with funding from the World Bank and the Danish Government (Foley et al. 1997).

\section{Narratives to explain forest degradation}

The diagnosis of forest degradation underpinning the HES blamed top-down forest policies inherited from the colonial period.

The studies that guided the HES mentioned various perturbations to explain forest degradation (Mahamane and Montagne 1997). However, they stressed mainly the links between ecosystem management and the urban consumption of firewood (Groupement Seed-CTFT 1994). A study on the firewood supply chain showed that demand in Niamey increased from $110,000 \mathrm{t}$ in 1983 to $133,000 \mathrm{t}$ in 1990 (3.2\% per year) (Groupement Seed-CTFT 1991). In this context of expected increasing demand, a combination of three main factors was suggested to explain forest degradation.

Firstly, degradation was explained mainly by a de facto situation of open access to forest resources (Mahamane and Montagne 1997). This situation was attributed to the appropriation of forest land by the State, combined with a lack of financial means in forest departments. Under these conditions, the Forest Department was not able to control forest harvesting, and access to forest resources was considered as free access (Madon and Matly 1986). Foley et al. (1997) described this situation as leading to overharvesting because wood traders from Niamey were guided mainly by short-term economic interests.
Secondly, the narratives justifying the HES explain forest degradation by the exclusion of rural people from forest management and from commercial harvesting of forest resources. By limiting the rights for commercial harvesting to urban traders and by centralizing forest management, forest policies did not encourage rural people to manage the forests (Groupement Seed-CTFT 1994, Foley et al. 1997, Mahamane and Montagne 1997).

These first two factors have been illustrated by Madon and Matly (1986:6):

These supply chains are predatory for the
environment: by economic rationale, the professionals
cut as closely and as quickly as possible, without
caring for resource regeneration. And no one is
stopping them: neither rural people as they are not
empowered in managing their land, nor forest
services, who practically never control the firewood
sector and harvesting areas.

Thirdly, the question of tree planting for firewood to supply urban households was examined by the HES, as the 1984 drought revealed the failure of such plantations (Groupement Seed-CTFT 1994). The production costs were deemed too high and survival rates too low in these arid areas (Foley et al. 1997). The forest experts involved in setting up the HES turned to the potential of natural woodlands and highlighted the lack of knowledge about harvested species regeneration (Foley et al. 1997). Investigations were thus deemed essential for developing sustainable harvesting rules that were adapted to woodland potential.

HES policy instruments to deal with forest degradation and ensure firewood supplies were developed in line with this diagnosis. The tools were implemented by the Household Energy Project, supported by the World Bank.

Policy instruments used in the Household Energy Project The Household Energy Project was organized in two parts. The demand aspect set out to reduce wood consumption by urban populations by developing alternative energy sources and by promoting the use of improved energy-efficient stoves. The supply aspect set out to improve the organization of firewood supplies at the local level and to manage forests sustainably (Foley et al. 1997). It was based on three main tools: the regional supply master plans, the rural firewood markets, and a new system of taxation on the wood trade.

The supply master plans were devised to set up RMs according to the distribution of wood resources within the supply basins of the main cities of the country: Niamey, Maradi, and Zinder. On the basis of a forest resource inventory, this strategy was intended to prevent firewood cutting where natural woodlands could not support such activity (Foley et al. 1997). 
RMs are key HES tools (Groupement Seed-CTFT 1994). They are defined as "places where organizations are set up for the commercial exploitation of firewood outside large towns" (République du Niger 1992), and are organized within an association called the "local structure of management" (LSM). But the RM concept is much broader than the notion of a wood trade site. RMs can be seen as similar to traditional wholesale crop markets in the Sahel, which are organized in production sites to gather all the production, to foster the transparency of supplies, and to allow traders from the urban consumption areas to arbitrate between various production sites (Galtier et al. 2012). However, they add new features to these characteristics: urban traders are supposed to have agreed with the LSM or the Forest Department to buy steres of wood (a cubic meter of stacked firewood) on the markets from the LSM. Wood quality, price, and origin are fixed by the nature of the RM. Around 250 RMs were created in Niger to empower local entities with the organization of firewood supplies and forest management. The establishment of an RM involves the identification of boundaries for the forest area whose management is devolved to rural people (a total of 680,000 ha of forest in 2004). All the villagers who have use rights in the designated forest area are allowed to harvest firewood within that area and to deliver it to a specific sales point of the RM where the traders can buy it. This new organization is intended to end open access by giving rural people responsibility for controlling forest harvesting and by increasing the wood stand value. The arguments behind the HES are as follows: if woodcutting is limited to the villagers who are forest-side residents, and if those villagers benefit from firewood harvesting, they will be encouraged to harvest the forest in a sustainable way (Montagne et al. 1997). Forest experts hypothesized that proximity to forest resources should induce better management, linking local poverty alleviation and sustainable forest use (Tacconi 2007).

To guarantee sustainable harvesting practices and sustainable income for RMs, forest experts proposed a forest management plan with technical rules to be enforced by woodcutters. These rules were based on studies of the regeneration capacity of trees after harvesting (Ichaou and D'Herbès 1997). Alongside these studies, the Forest Department assessed the stocks of firewood within each RM forest area to define the annual allocation of wood for harvesting as a collective quota for the LSM (Mahamane and Montagne 1997).

The third HEP tool for dealing with forest degradation was wood trade taxation directly collected by the LSM manager from the traders on each transaction. This withholding tax of 300 to 375 CFA F $^{[1]}$ per stere was devised according to the distance from the city and the RM type. Tax revenues are distributed between LSMs, the rural council, and the State treasury as apportioned by Order 92-037 (Montagne 1997). The terms of use for these funds are also fixed: a share has to be invested in forest management (tree planting, control). This new taxation system increases rural people's collective income and the Forest Department financial budget to ensure controlled firewood harvesting. The graduated taxation according to the distance from cities is intended to dissuade harvesting near cities and thus prevent overharvesting of those areas.

This explanation of forest degradation and the subsequent tools to deal with it reveal specific representations of the issue of forest management. We highlight these representations by referring to the vulnerability framework.

\section{Highlighting the representations underlying the Household Energy Strategy using the vulnerability framework}

The HES can be regarded as a vulnerability diagnosis solution. The diagnosis of forest degradation presented above can be described with the vulnerability framework of Turner II et al. (2003) (Fig. 1).

Fig. 1. Degradation diagnosis underlying the Household Energy Strategy analyzed as a vulnerability diagnosis (adapted from Turner II et al. 2003).

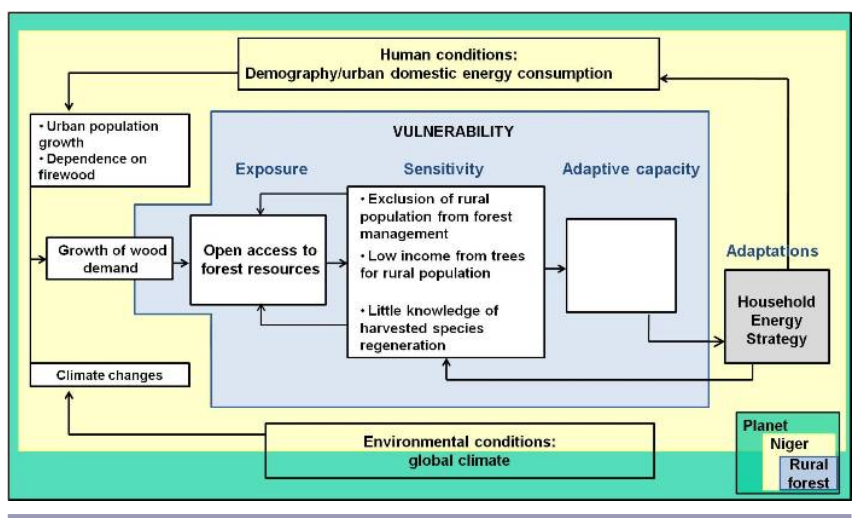

This analysis of the forest degradation diagnosis as a vulnerability diagnosis highlights a break with previous policies and the will to understand the failures within the system instead of trying to stop the perturbations. However, our analysis of the tools designed to change the system shows the pitfalls of such an approach in terms of vulnerability. The focus on one perturbation and on specific components of the system prevents any consideration of the forest management issue as a whole.

\section{Comparable degradation and vulnerability diagnoses}

Figure 1 shows the main vulnerability components (perturbation, exposure, sensitivity, and adaptive capacity) that can be identified from the analyzed documents and interviews. The HES appears as the solution for dealing with the diagnosed problem. Each component is described in the following sections. 
The main perturbation considered in the diagnosis of forest degradation was the increasing urban demand for firewood. The HES focused on the increasing demand for firewood, and the failure of the forest management system was analyzed specifically according to that perturbation.

The issue of "open access" to forest resources can be seen as an exposure condition (Fig. 1) because open access establishes the contact between the system (social and ecological components) and the perturbation, i.e., urban demand. This linkage defines exposure in the vulnerability approach.

The sensitivity conditions (exclusion of rural population, low incomes, limited knowledge of harvested species regeneration) are presented in the middle square in Figure 1. We consider these causes of forest degradation identified in the HES reports as sensitivity factors because they form the conditions that make the system vulnerable to the demand for firewood. Sensitivity factors are interdependent and dependent on exposure.

The right-hand section of Figure 1 shows that no adaptive capacity was identified within the system. Adaptations were supposed to originate from the national level with the regional master plans and a reorganization of firewood supply conditions designed in the HES.

Forest policy reforms in Niger were drawn up and justified according to the fear of a firewood shortage. Unlike previous policies, they acknowledged that forest harvesting for firewood supplies could not be stopped, and analyzed the dysfunctions within the system in order to change them.

\section{Actions targeted on firewood}

The strategy behind the HES is to reduce both the perturbation and the vulnerability of the forest management system through the demand and supply aspects of the project, respectively. The following analysis focuses on the supply aspect and specifically on the RMs which are key HES tools.

One specificity of the vulnerability approach is to consider the relativity of vulnerability within the system (Turner II et al. 2003). When looking at a specific perturbation, several subsystems or components of the considered system present differential vulnerabilities. The same principle characterizes the forest degradation diagnosis that underlies the HES. This diagnosis looks specifically at the increasing demand for firewood and specifically considers the vulnerability of firewood provision within the forest management system.

By using this type of approach, the HES aims to achieve sustainable management for the whole system, but its actions target only certain components of the system.

In the open access issue, RMs were charged with controlling access to firewood resources. However, the open access issue is not restricted to firewood. This strategy highlights two HES premises. Firstly, open access concerns only firewood resources. Secondly, open access is more an issue of harvesters' profiles and unclarified harvesters' rights than an issue of the number or choice of harvesters.

As regards sensitivity conditions, with the establishment of RMs the State recognizes management rights for rural people and allows them to increase their income from forest resources by harvesting and selling firewood. However, the new forest management and commercial harvesting rights, as well as the new forest resource harvesting rules, target a specific resource, i.e., firewood. The changes introduced by the HES are thus intended for rural people who are involved in firewood harvesting and for certain species that provide that resource.

Achieving sustainable management of rural forests involves taking into account their global functioning (GarciaFernandez et al. 2008, Guariguata et al. 2012). The changes introduced by the HES with regard to firewood provision may have indirect effects on other forest uses. Rural people who become involved in woodcutting also have other activities, and they interact with other rural forest users. Forests that supply firewood may also supply other products. Synergies and trade-offs are thus likely to occur between the various uses that characterize Sahelian rural forests.

To study HES effects on these rural forests, we need an approach that understands their complexity and the evolution of many interactions within Sahelian rural forests.

\section{UNDERSTANDING HOUSEHOLD ENERGY STRATEGY EFFECTS ON RURAL FORESTS}

To analyze how the HES affects rural forests, we use the concept of the social-ecological system in order to conceptualize rural forests as complex systems characterized by several interactions and feedbacks (Berkes and Folke 1998a, Ostrom 2009). Such an approach highlights the coevolution between humans and ecosystems. To assess the changes linked to interactions between social and ecological dynamics, we introduce the concept of the social-ecological function. SES functions are defined as the processes emerging from interactions between components of the social and ecological systems. A function, such as firewood provision, depends on both the people harvesting wood and the trees producing it. The changes in SES function may be qualitative and/or quantitative depending on the nature and number of actors, and the nature and quantity of ecosystem components that contribute to the function. This focus on functions can provide an insight into the social dilemma induced by the chosen management options in the HES to sustain forests for firewood provision. Rural populations may have conflicting forest uses, but conflicts may also arise between the individual interests of stakeholders involved in the HES and community interests.

The changes driven by the HES in forest management were studied by considering the evolution of interactions between 
SES functions. Our analysis was based on an empirical study in the village of Ninpelima, where an RM was set up in 1993. We identified 16 functions in the Ninpelima SES (Appendix 1 ), and we analyzed their interactions by observing trade-offs and synergies.

\section{Social-ecological functions to analyze Household Energy Strategy effects on the Ninpelima rural forest}

\section{Ninpelima rural forest}

The area of Ninpelima is located in the southern part of the Niamey supply basin in Niger (Fig. 2). Five hamlets form the village of Ninpelima with a population of about 50 Fulanis and 320 Gourmantches (census carried out in 2009—only with adults-as part of our study). The Ninpelima RM was among the first to be created in Niger, and its forest area covers 7940 ha. It is still functioning (Appendix 2), and the area is a typical example of rural forest with multiple interactions between users and forest ecosystems. The importance of SES functions in villagers' livelihoods and incomes varies between the different actors (Appendix 3). Since the Gourmantches settled there 400 years ago, ecological dynamics and human practices have coevolved to build a heterogeneous landscape that reflects the diversity of their interactions (Fig. 2). The natural woodlands cover 5890 ha and are located mainly between the plateaus and the lowlands. The crops are located mostly near the valleys (1024 ha). Ninpelima has a typical Sahelian croplivestock farming system where people depend on a wide range of forest products.

Fig. 2. Location of the rural firewood market of Ninpelima, and land cover of the area (Rural Council of Torodi, Say Department, Tillaberi Region).

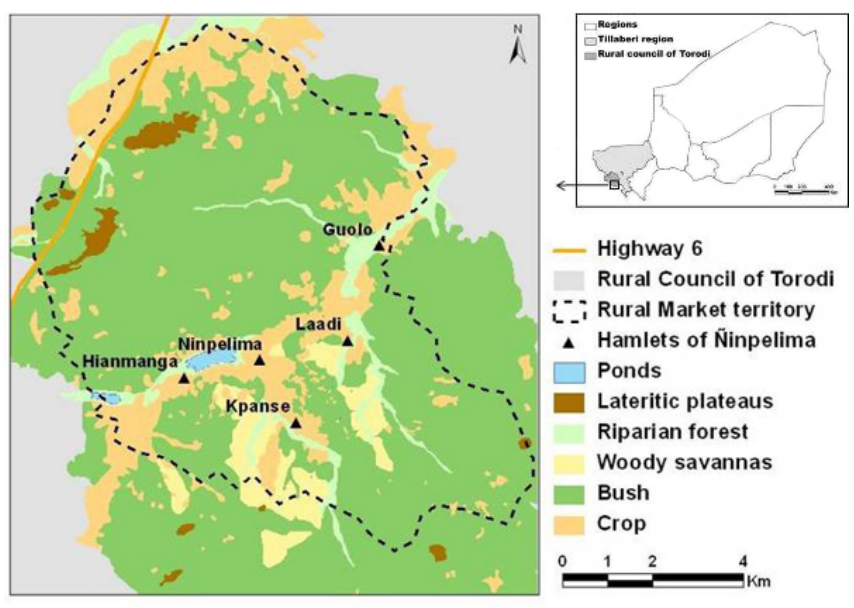

Interactions between social-ecological system functions Observing concomitant changes in several functions is a way of establishing their interdependence, qualified as trade-offs or synergies (Bennett et al. 2009).
Bennett et al. (2009) suggested a typology to improve understanding of the mechanisms behind the observed relations between ecosystem services, i.e., trade-off or synergy. This typology distinguishes whether observed relations between two or more ecosystem services (ES) result from the impact of a common driver or from a "true" interaction between ES.

Building on this typology, we further characterized the "true" interactions between SES functions as competition or mutual benefit. Competition is a situation in which some components of the ecological or social system are unable to contribute to two SES functions at the same time or in the same location (for example, the number of stakeholders in a group is insufficient for them to be involved in both agriculture and livestock production). Mutual benefit is a case where SES functions may take mutual advantage of their interaction even though they are able to operate independently.

The changes in functions and thus the relations observed between them (trade-off or synergy, Fig. 3a) result from the combined effect of different types of interactions (competition and/or mutual benefit, Fig. 3b). Such interactions may come from sharing ecological or social components (e.g., a species or a stakeholder group) between functions (Fig. 3c).

Fig. 3. Different steps explaining the observed relations between social-ecological systems functions.

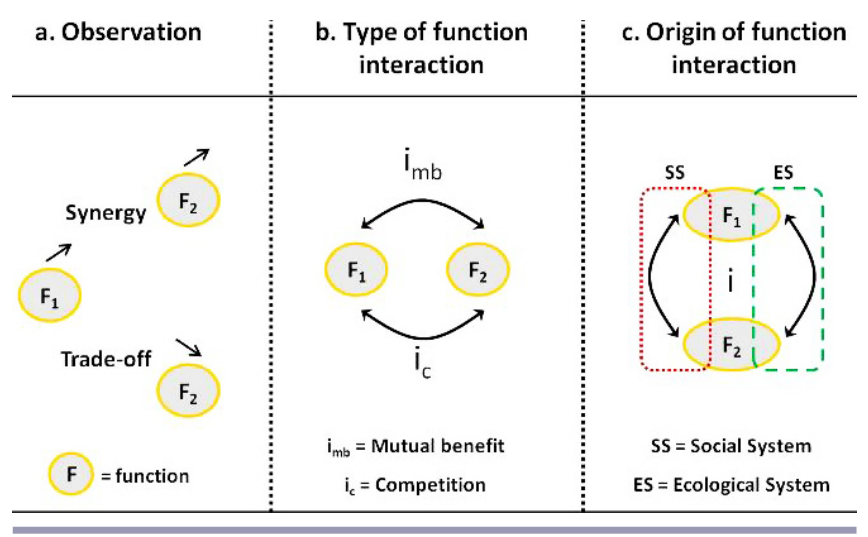

The diversity of functions was explored by questioning various stakeholders about their uses of the different ecosystem components. The survey involved 109 villagers out of the total of 369 people living in Ñinpelima. The sample was designed to reveal the role of gender, age, place, and ethnic diversity given that their contribution to, and their perception of, SES functions might differ (Table 1).

We then analyzed the changes in SES functions by asking respondents about the changes in their activities and practices since they began them. In addition, we asked them explicitly to detail these changes. Quantitative changes (e.g., firewood provision) were evaluated on the basis of three types of 
Table 1. Sampling in the Ninpelima survey.

\begin{tabular}{|c|c|c|c|c|c|c|}
\hline \multirow[b]{2}{*}{$\begin{array}{l}\text { Hamlets included in the rural } \\
\text { market of Ninpelima }\end{array}$} & \multirow[b]{2}{*}{$\begin{array}{l}\text { No. Fulbe } \\
\text { villagers }\end{array}$} & \multicolumn{2}{|c|}{ Fulbe respondents } & \multirow[b]{2}{*}{$\begin{array}{c}\text { No. } \\
\text { Gourmantche } \\
\text { villagers }\end{array}$} & \multicolumn{2}{|c|}{ Gourmantche respondents } \\
\hline & & No. men/women & $\begin{array}{l}\text { Sampling rate } \\
(\%)\end{array}$ & & No. men/women & $\begin{array}{c}\text { Sampling rate } \\
(\%)\end{array}$ \\
\hline Guolo & 0 & 0 & & 43 & $8 / 6$ & 32.6 \\
\hline Hianmanga & 0 & 0 & & 51 & $5 / 6$ & 21.6 \\
\hline Kpanse & 22 & $2 / 3$ & 22.7 & 51 & $8 / 10$ & 35.3 \\
\hline Laadi & 15 & $2 / 4$ & 40.0 & 47 & $11 / 9$ & 42.6 \\
\hline Ninpelima & 10 & $2 / 1$ & 30.0 & 130 & $16 / 16$ & 24.6 \\
\hline Total & 47 & $6 / 8$ & 29.8 & 322 & $48 / 47$ & 29.5 \\
\hline
\end{tabular}

indicator for each function: the number of stakeholders involved (e.g., the number of woodcutters), the quantity of ecological component (e.g., quantity of wood found by woodcutters), and the quantity of product (e.g., the quantity of wood sold in the RM). Qualitative changes were analyzed according to the type of actors involved in the function (gender, age, ethnic group, village), the harvested species, the ecosystem used, and the harvesting places. Such an analysis of quantitative and qualitative changes is relevant because no technical changes in harvesting or farming efforts occurred over the studied period. In their responses, we found that the villagers spontaneously identified changes specifically related to the establishment of the RM.

Lastly, we identified and analyzed the interactions between SES functions as mentioned above.

\section{Evaluating the direct effects of the rural firewood market on targeted social-ecological systems}

The components considered by the HES were conceptualized as sub-SES of the rural forest, defined according to firewood provision. We called this the targeted SES, whereas the rural forest of Ninpelima was conceptualized as the global SES.

The HES intentionally introduced changes in the targeted SES. The creation of the RM introduced a new management entity (LSM) and new rules for firewood species harvesting. The rural population acquired a new role in organizing and controlling firewood harvesting and trade. Because the rural population now has the right to harvest and sell firewood within a quota, its relations with urban wood traders have moved towards more power to negotiate. ${ }^{[2]}$ According to Ninpelima woodcutters, the price per stere increased from 400-600 CFA F in 1989 to 1250 CFA F in 1994, and to 15002500 CFA F (variations depended on the woodcutters and on the season; prices rose in the rainy season) in 2009. These conditions have encouraged rural people to invest in woodcutting activities.

All these changes led to qualitative and quantitative changes in the firewood provision function due to social and ecological changes, as illustrated in Figure 4.
The number of woodcutters in Ninpelima increased from 13, when the RM was created in 1993, to 45 in 2000, and to 50 in 2009. ${ }^{[3]}$ The quantity of harvested firewood has increased since 2003 (Fig. 4), maybe as a result of the combined effects of the increase in the number of woodcutters (Fig. 4a) and in urban firewood demand, and new accessibility (since 2003) to the rural market during the rainy season (Fig. 4b). Conversely, firewood trade was disturbed from 1997 to 2000 because accessibility was limited by damage to Highway 6. Apart from this period, the quota was exceeded each year.

The increase in harvested wood has an effect on the tree population. The first phase concerns the transition from dead to live tree harvesting (Fig. 4c). The stock of dead trees probably resulted from the droughts in the 1970s and 1980s. Because this stock was not renewed, woodcutters gradually started harvesting live trees. Since 2005, only live trees have been harvested. In the second phase, woodcutters broadened the range of harvested species (Fig. 4d). At the beginning, they harvested stems mainly from Combretum nigricans and Anogeissus leiocarpus, which produce the consumers' preferred firewood. When the large stems of these species became scarce, the woodcutters began harvesting Combretum micranthum, Guiera senegalensis, Combretum glutinosum, and Piliostigma reticulatum. The third phase is characterized by a reduction in the diameter of harvested stems (Fig. 5) caused by the short regeneration time left to the trees. However, the stems are regenerating because most Sahelian species reproduce by vegetative propagation (Bellefontaine 1997). The development of live tree harvesting also opened the way to wood sales from fallow clearing. In spite of burning this wood to fertilize future fields, $18 \%$ of woodcutters sold it in the RM.

The villagers' involvement in woodcutting - although they have other activities - and the increase in woodcutting effects on several species-which are also harvested for other uses beside firewood-led to the development of new interactions between the function of firewood provision and the other functions of the global SES. These interactions could occur through the actors as well as the resources. 
Fig. 4. Changes in the Ninpelima rural firewood market from 1995 to 2007 (source: LSM ledger and interviews).

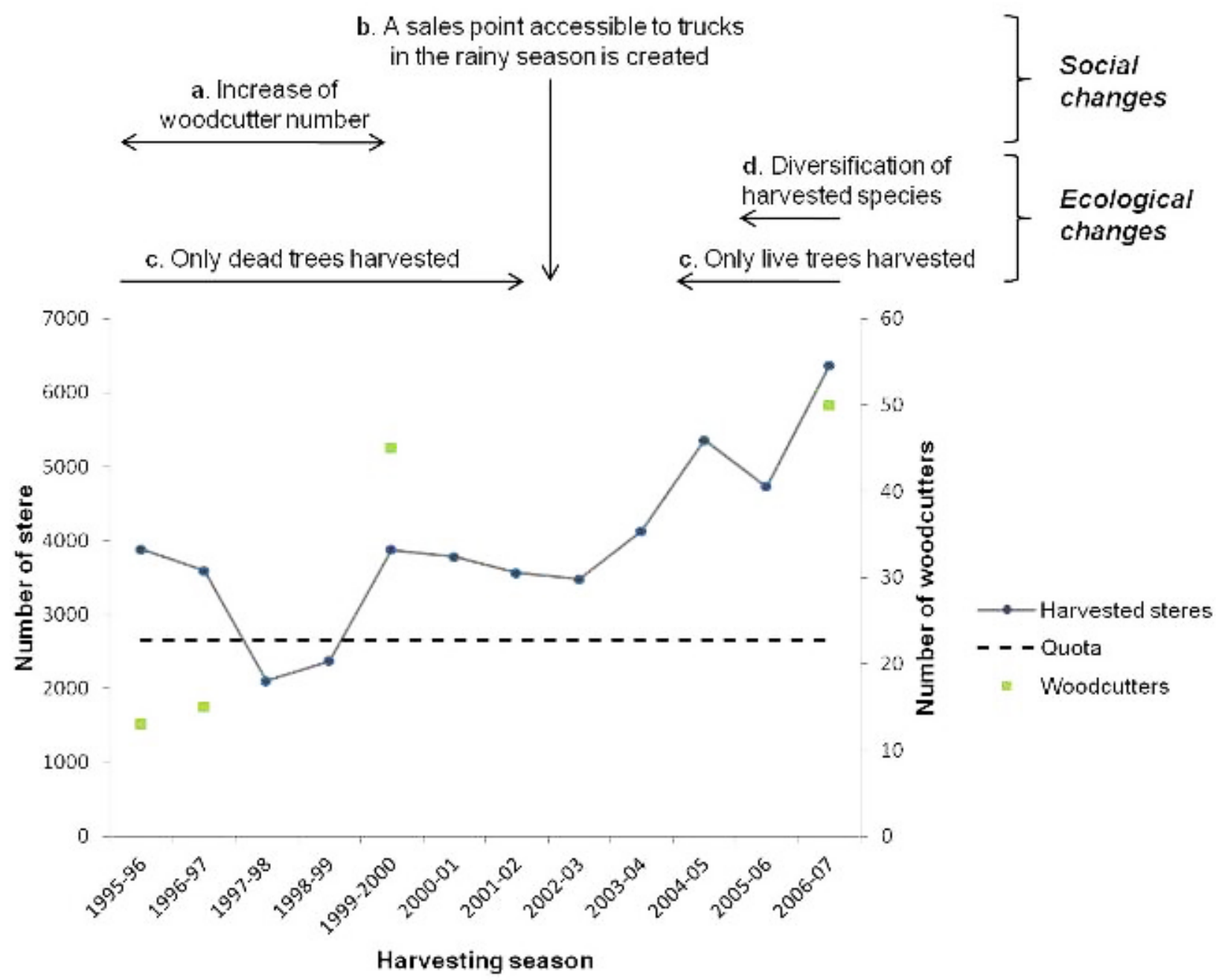

\section{Emergence of new interactions between social-ecological system functions}

The changes induced by the establishment of the RM had a different impact on the 16 functions of the global SES. In the following sections, we present two other major functions which, according to the survey, changed significantly: gum provision and livestock production (Table 2).

The examples of changes in firewood and gum provision and livestock production enabled us to illustrate different interaction setups that explained the observed relations between SES functions (Fig. 6).

Trade-off observed between gum and firewood provision: result of two competitions

The trade-off observed between gum and firewood provision functions results from the combination of two competitions.
These competitions have induced qualitative and quantitative changes in the gum provision function.

Firstly, competition for the workforce between the two functions led to changes in the group who contributed to the gum provision function. Most of the young men who worked in gum harvesting switched to woodcutting because it was more profitable. Women are now the only gum harvesters, and their harvesting effort was stable over the studied period.

Secondly, competition between the two functions for Combretum nigricans caused a scarcity of gum. Women mentioned a $17-71 \%$ drop in their gum harvest, depending on the respondents, between 1990 and 2009 (measured by the number of cups, the unit used for selling gum). In Niger, marketed gum is produced by three species. Acacia senegal and $A$. seyal gums are the only ones designated as gum arabic. Since these species are rare in Ninpelima, the gum provision 
Table 2. Changes in three social-ecological system functions in Ninpelima.

\begin{tabular}{|c|c|c|c|}
\hline Function & Firewood & Livestock & Gum \\
\hline "Quantitative" change & + & + & - \\
\hline $\begin{array}{l}\text { Indicators of quantitative } \\
\text { change }\end{array}$ & $\begin{array}{l}\text { Increase in the number of } \\
\text { woodcutter } \\
\text { Increase in the number of cubic } \\
\text { meters sold }\end{array}$ & $\begin{array}{l}\text { Increase in the number of } \\
\text { livestock herder } \\
\text { Decrease in the number of } \\
\text { livestock sold }\end{array}$ & $\begin{array}{l}\text { Decrease in the quantity of gum } \\
\text { harvested per woman }\end{array}$ \\
\hline \multirow{2}{*}{$\begin{array}{l}\text { Indicators of qualitative } \\
\text { change }\end{array}$} & Harvesting of live trees & Decrease in fodder & \\
\hline & $\begin{array}{l}\text { Decrease in diameter of } \\
\text { Combretum nigricans and other } \\
\text { harvested species }\end{array}$ & & $\begin{array}{l}\text { Decrease in the number of large } \\
\text { diameter stems of Combretum } \\
\text { nigricans that produce gum }\end{array}$ \\
\hline
\end{tabular}

function depends mainly on $C$. nigricans. This species is also the most popular with firewood consumers. The reduction in the average stem diameter of $C$. nigricans reduced gum provision in this species.

Fig. 5. Size of harvested stems in 2005 and 2009 according to 28 woodcutters (average and standard deviation).

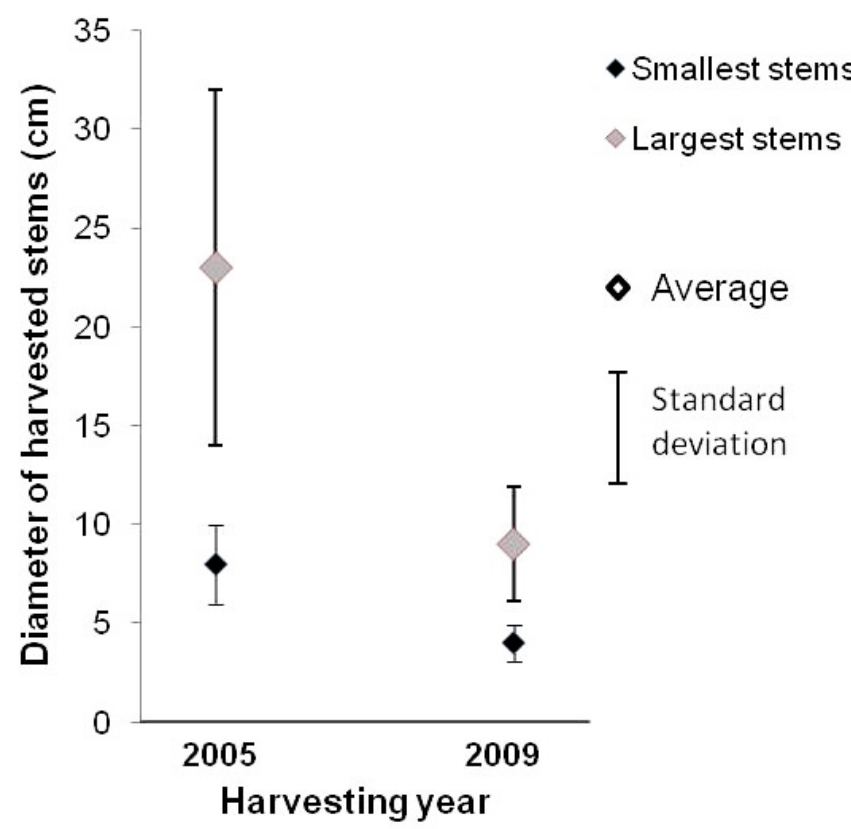

Competition is at the expense of gum provision because this function depends on one specific species. Moreover, the low market price of gum and the weak power of the women restricted their ability to establish rules to protect $C$. nigricans.
Fig. 6. Relations observed and interactions between functions of firewood and gum provision and livestock production.

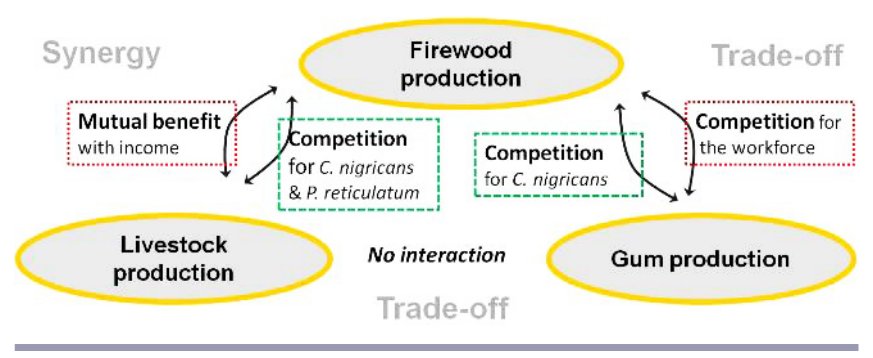

Synergy observed between livestock production and firewood provision: result of combined competition and mutual benefits

The synergy observed between livestock production and firewood provision results from a combination of competition and mutual benefits between the two functions.

Livestock production has benefited in two ways from the increase in firewood provision. Firstly, this increase minimized the interaction between livestock and farm production functions. Although woodcutters and their families had to sell livestock to cope with frequent poor foodcrop harvests because of climate events before the creation of the $\mathrm{RM}$, the latter has since compensated for those shortages with the income from firewood. This change has contributed to the increase in livestock in Ninpelima. Among the 48 respondents who perceived a positive RM impact, buying food to cope with shortages was the second benefit cited (33\% of respondents), and buying livestock was the third ( $25 \%$ of respondents). Firewood provision also had a direct effect on livestock quantity because income from firewood was invested in 
livestock purchases. Among the 38 woodcutters interviewed, $90 \%$ had livestock and $35 \%$ had invested in livestock by using firewood income.

Despite this synergy, some stakeholders mentioned a competitive interaction between the two functions for some fodder tree species. C. nigricans and Piliostigma reticulatum are species that are harvested for firewood and are also used to produce fodder at the end of the dry season. Moreover, Fulani breeders frequently mentioned the impact of firewood harvesting on pasture quality because this activity opens up bush and savanna ecosystems. Conversely, the livestock increase in the Ninpelima rural forest did not affect forest conditions because pruning, as practiced by Gourmantche livestock breeders, is not a practice that alters the forest stand (Petit 2000).

\section{DISCUSSION}

Our results show that understanding forest degradation by taking a vulnerability position leads to a selective diagnosis. In this approach, the HES could not achieve its objective of sustainable forest management because it focused on specific components of the SES and did not anticipate interactions between the various functions that characterize Sahelian rural forests.

In the following sections, we discuss (1) the changes and continuations that characterize the HES according to the narratives used in the policy agenda, (2) the SES scale issue raised by the distinction between targeted and global SES, and (3) the relevance of using the concept of SES functions and their interactions.

\section{The Household Energy Strategy: a new image of firewood use and of forests?}

The HES designers promoted forest management decentralization as a turning point in natural resource management policies in Africa. The main changes put forward were the reconsideration of State dominance over forest management and the recognition of local forest management practices of rural populations (Bertrand et al. 2006). However, some authors consider that the transfer of rights to rural people has been incomplete (Ribot et al. 2006), or that scientific forestry (quota, limits, and management plans), originating from the colonial period, is still operating (Gautier et al. 2012). These publications provide an insight into what changed and what was upheld in the implementation of decentralization policies.

Our study of the HES highlighted what changed or was upheld in the image of Sahelian forests, which guided the solutions suggested by forest policy reforms. The forest experts involved in the HES challenged the "worst case scenario" of a fuelwood crisis which led to policies focused on plantations (Foley et al. 1997). Yet, the HES justified its stance based on the same kind of scenario. Although a shortage was obviously postponed, the HES experts were still predicting it ("the sustainable supply for Niamey and Zinder would be exceeded by the year 2000" [Foley et al. 1997]). The HES designers paid little attention to the contemporary studies that challenged the linear relationship between population growth, fuelwood consumption, and forest degradation (Cline-Cole et al. 1990, Fairhead and Leach 1995). Fuelwood use is still depicted in the same way in energy policies, and that is also found in other African countries and in South Asia (Arnold et al. 2006). This reflects the contingency and unicity of the framing used in the HES, thereby preventing a debate from opposite viewpoints on the identified problem (risk of firewood shortage and forest degradation), the proposed measures (rural firewood markets), and the expected impacts (sustainable forest management).

Although the HES did not challenge the representation of the perturbation (i.e., increased firewood demand), it broke with the analysis of the reasons for forest degradation. The previous policies, focused on tree planting to deal with the problem of firewood supplies, tackled the problem as an inability of Sahelian woodlands to supply sufficient quantities of wood. The HES questioned the capacity of society, in the context at the time, to manage woodlands. Using the phrase of Tschakert (2007), the HES turned the diagnosis of forest degradation from a problem for society to a problem of society. Previous policies focused on the perturbation and its impacts. They resorted to technical solutions to limit the impacts of the increasing demand for firewood, i.e., to tree planting. In the context of policies to adapt to climate change, Tschakert (2007) criticized such approaches and suggested concentrating more on sensitivity and adaptive capacity, which are the other two determinants of vulnerability. By analyzing forest degradation as a dysfunction within the system (exclusion of rural populations, low incomes, little knowledge of harvested species regeneration), the HES identified the conditions of sensitivity and sought to reduce them. However, the HES did not consider local adaptive capacities, i.e., the ability of rural populations to cope with the perturbations affecting their forest resources. As a consequence, the HES did not reinforce local adaptive capacities, such as the capacity to reformulate local arrangements between resource users according to social and ecological changes, or the capacity to diversify their activities to cope with these changes (Batterbury 2001, Raynaut 2001).

\section{Household Energy Strategy effects depend on the scale of analysis}

The distinction between targeted and global SES raises the issue of the appropriate SES scale when assessing HES effects. Although the targeted SES may be considered as a subsystem of the global SES, both SES are identified at a local organizational level and are spatially bound to the same area which covers the village territory (five hamlets).

Our original hypothesis was that well-defined levels of spatial and organizational scales would automatically lead to the 
identification of the SES. But in reality, different SES may be identified since they are at different levels in a functional scale. The need for this distinction emerged when we tried to identify which SES components were targeted by the HES and which were impacted. The targeted SES is defined at a monofunctional level that includes only the firewood provision function, whereas the global SES is defined at a multifunctional level on a functional scale (Fig. 7).

Fig. 7. Position of global and targeted social-ecological systems on spatial, organizational, and functional scales.

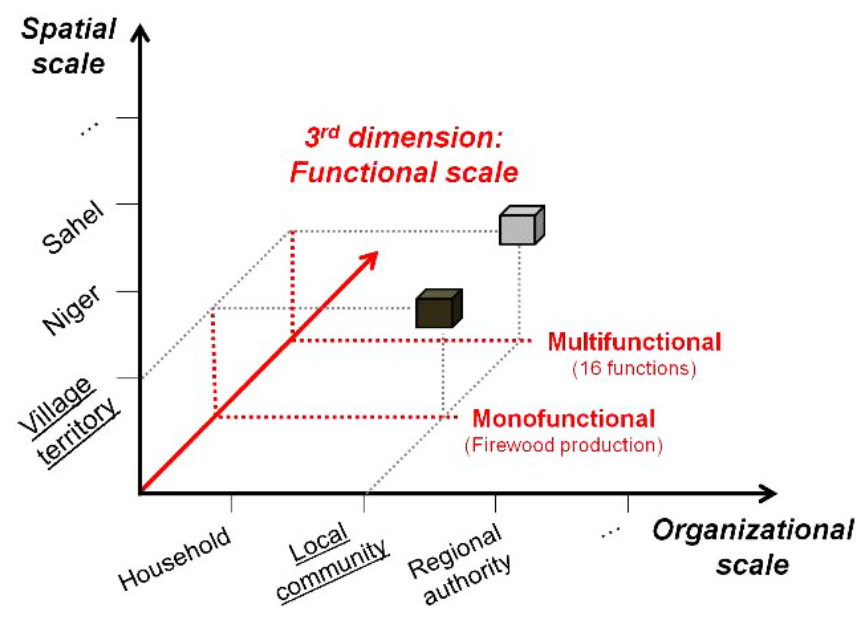

Although the HES targeted one function (firewood provision) to improve forest management, the effects on the global SES were probably not anticipated. From a management perspective, we can conclude that even if forest management strategies are focused on a monofunctional level so as to reduce the vulnerability of the SES, they may change the trajectory of a larger system since functions interact. Consequently, the institutions and rules that were designed to implement the HES towards forest sustainabilty, clarification of rights over the resource base, and creation of rural income were not tailored to consider the issues involved in mediating a larger range of human-environment interactions. Similar arguments are found in discussions on general and specified resilience (Walker and Salt 2006, Miller et al. 2010). As the HES focused on one specific perturbation and identified one specific SES, it sought to build the resilience of that SES to this perturbation, i.e., specified resilience. When observing the larger SES, we can conclude that "optimizing for one form of resilience can reduce other forms of resilience" (Walker and Salt 2006).

\section{Social-ecological system functions and interactions to understand the dynamics of a complex system}

Issues dealing with mono/multifunctional SES or general/ specified resilience refer to various levels of complexity and interactions that need to be borne in mind when trying to understand changes in SES characterized by multiple users, multiple uses, and multiple ecosystems and species.

We have argued that the concept of SES functions reinforces integration because it describes a social-ecological unit at an SES sublevel. Such a social-ecological analytical unit is essential for understanding changes in complex systems.

The need to consider adequately the coupling effects of social and ecological dynamics within SES has been emphasized in studies on interactions between ecosystem services (ES) (Bennett et al. 2009) and on the identification of thresholds in ES provision (Renaud et al. 2010). Renaud et al. (2010) highlighted the limits of the ES concept in the integration of social regulations. ES are defined as "the benefits people obtain from ecosystems" (Millennium Ecosystem Assessment 2003). In ES studies, interactions are observed through human dependency on ecosystems, through the impact of human activities on ecosystems, and/or through the production of ES by human-dominated ecosystems (Barnaud et al. 2011). Although the ES concept has greatly helped highlight the dependency of humans on ecosystems, its common definition underplays the role of social regulations in the creation of, and changes in, ES. This concept was initially intended to emphasize the value of ecosystem functions for humanity (Ehrlich and Ehrlich 1981) and to raise people's awareness that "ecosystems serve us" (Peterson et al. 2009).

Bennet et al. (2009) and Renaud et al. (2010) suggest that ES should be defined not only by their provision by ecosystems but also by social data encompassing management actions or uses of ES (Bennett et al. 2009, Renaud et al. 2010). The concept of SES functions addresses that need by integrating social regulations and uses into ecological processes and products. At the multifunctional level, the analysis of interactions between SES functions helps in understanding changes in the larger system. The function concept considers the social and/or ecological origin of interactions without considering social regulations as an external factor.

\section{CONCLUSION}

The HES focused on SES that were identified on a local scale and defined through a diagnosis comparable to a vulnerability approach. As the main perturbation identified was the increasing urban demand for firewood, these SES were defined as the functions of firewood provision, together with the social and ecological components contributing to it. This reform reviewed important principles, such as the State's monopoly of forest management and the economic rationale of wood harvesting, but it did not question the representation of wood as the only function of Sahelian forests, as well as the only forest livelihood support. Yet, Niger is, for example, the fourth largest gum producer in Africa.

The strategies for changing the conditions within this targeted SES in the case studied had an impact on a larger SES 
consisting of 15 other functions - in addition to firewood provision-and of social and ecological components contributing to them because the firewood provision function interacted with the other functions. Following the introduction of the HES, the functions of firewood provision and livestock production became more significant in the SES, whereas the opposite was true for gum provision. The imbalance between SES functions may increase SES vulnerability-or in other words, reduce general resilience-since we consider that the diversity of functions increases SES adaptive capacity.

Where Sahelian forest management is concerned, interactions between SES functions should be considered. Such an approach is helpful for identifying the potential trade-offs within a social group or between several species. Observing these interactions may help policies reshape some rules on forest harvesting and eventually recognize the potential contribution of certain actors or local institutions in balancing SES functions. Scholars in ecosystem adaptive management suggest using management interventions to learn about ecosystem functioning and to adapt management (Berkes et al. 2000). Building on such an approach, analyzing SES function interactions should be used to learn about SES functioning and adapt policies for improved rural forest management. Monitoring SES function interactions would promote a balance of power among local resource users and enhance the adaptive capacities of rural people.

Responses to this article can be read online at: http://www.ecologyandsociety.org/issues/responses. php/5182

\section{Acknowledgments:}

We thank Elin Enfors and Garry Peterson for helpful comments on the first version of this manuscript; Aurélie Botta for her help with figures; and Marie-Cécile Maraval and Peter Biggins for English reviewing. We also thank the two anonymous reviewers for their thoughtful comments and suggestions. This work was supported by the "Gesforcom" project funded by the European Union and by a scholarship from CIRAD.

\section{LITERATURE CITED}

Adger, W. N. 2006. Vulnerability. Global Environmental Change 16:268-281. http://dx.doi.org/10.1016/j. gloenvcha.2006.02.006

Antona, M., and A. Bertrand. 2006. Politiques forestières et instruments de gestion forestières. Pages 134-168 in Forêts tropicales et mondialisation: les mutations des politiques forestières en Afrique francophone et à Madagascar. L'Harmattan, Paris, France.
Antona, M., P. Bommel, F. Bousquet, and C. Le Page. 2002. Interactions and organization in ecosystem management: the use of multi-agent systems to simulate incentive environmental policies. Pages 85-92 in 3rd Workshop on agent-based simulation Erlangen: SCS European Publishing House, Passau, Germany.

Arnold, J. E. M., G. Köhlin, and R. Persson. 2006. Woodfuels, livelihoods, and policy interventions: changing perspectives. World Development 34:596-611. http://dx.doi.org/10.1016/j. worlddev.2005.08.008

Aubert, S. 2003. La gestion patrimoniale. Pages 179-183 in S. Aubert, S. Razafiarison, and A. Bertrand, editors. Déforestation et systèmes agraires à Madagascar: les dynamiques des tavy sur la côte orientale. Cite-Cirad-Fofifa, Montpellier, France.

Babin, D., and A. Bertrand. 1998. How to manage pluralism: subsidiarity and patrimonial mediation. Unasylva 49:19-25.

Barnaud, C., M. Antona, and J. Marzin. 2011. Vers une mise en débat des incertitudes associées à la notion de service écosystémique. VertigO 11.

Batterbury, S. 2001. Landscapes of diversity: a local political ecology of livelihood diversification in south-western Niger. Ecumene 8:437-464.

Bellefontaine, R. 1997. Synthèse des espèces des domaines sahélien et soudanien qui se multiplient naturellement par voie végétative. Pages 95-104 in J. M. D'Herbès, J. M. K. Ambouta, and R. Peltier, editors. Fonctionnement et gestion des écosystèmes forestiers contractés sahéliens J. Libbey Eurotext, Paris, France.

Béné, C., E. Belal, M. O. Baba, S. Ovie, A. Raji, I. Malasha, F. Njaya, M. Na Andi, A. Russell, and A. Neiland. 2009. Power struggle, dispute and alliance over local resources: analyzing 'democratic' decentralization of natural resources through the lenses of Africa inland fisheries. World Development 37:1935-1950. http://dx.doi.org/10.1016/j.worlddev.2009.05.003

Benjaminsen, T. 1997. Natural resource management, paradigm shifts, and the decentralization reform in Mali. Human Ecology 25:121-143. http://dx.doi.org/10.1023/ A:1021940004348

Bennett, E. M., G. D. Peterson, and L. J. Gordon. 2009. Understanding relationships among multiple ecosystem services. Ecology Letters 12:1394-1404. http://dx.doi. org/10.1111/j.1461-0248.2009.01387.x

Berkes, F., J. Colding, and C. Folke. 2000. Rediscovery of traditional ecological knowledge as adaptive management. Ecological Applications 10:1251-1262. http://dx.doi. org/10.1890/1051-0761(2000)010[1251:ROTEKA]2.0.CO;2

Berkes, F., and C. Folke. 1998a. Linking social and ecological systems for resilience and sustainability. Pages 1-25 in F. 
Berkes and C. Folke, editors. Linking social and ecological systems. Management practices and social mechanisms for building resilience. Cambridge University Press, Cambridge.

Berkes, F., and C. Folke. 1998b. Linking social and ecological systems. Management practices and social mechanisms for building resilience. Cambridge University Press, Cambridge.

Bertrand, A. 1985. Les nouvelles politiques de foresterie en milieu rural au Sahel. Réglementations foncières et forestières et gestion des ressources ligneuses naturelles dans les pays de la zone soudano-sahélienne. Bois et Forêts des Tropiques 207:23-39.

Bertrand, A., and P. Montagne. 2006. Les difficiles mutations des politiques forestières: d'une gestion autroritaire et exclusive vers une politique publique intégrée. Pages 37-53 in A. Bertrand, P. Montagne, and A. Karsenty, editors. L'état et la gestion locale durable des forêts en Afrique francophone et à Madagascar. L'Harmattan, Paris, France.

Bertrand, A., P. Montagne, and A. Karsenty. 2006. L'état et la gestion locale durable des forêts en Afrique francophone et à Madagascar. Page 471. L'Harmattan, Paris, France.

Buttoud, G. 2001. Gérer les forêts du sud: l'essentiel sur la politique et l'économie forestières dans les pays en développement. L'Harmattan, Paris, France.

Chomitz, K. M., and C. W. Griffiths. 1997. An economic analysis of woodfuel management in the Sahel. The case of Chad. World Bank, Washington, D.C., USA. http://dx.doi. org/http://dx.doi.org/10.1596/1813-9450-1788

Cline-Cole, R. A., H. A. C. Main, and J. E. Nichol. 1990. On fuelwood consumption, population dynamics and deforestation in Africa. World Development 18:513-527. http://dx.doi. org/10.1016/0305-750X(90)90068-9

Collins, S. L., S. R. Carpenter, S. M. Swinton, D. E. Orenstein, D. L. Childers, T. L. Gragson, N. B. Grimm, J. M. Grove, S. L. Harlan, J. P. Kaye, A. K. Knapp, G. P. Kofinas, J. J. Magnuson, W. H. McDowell, J. M. Melack, L. A. Ogden, G. P. Robertson, M. D. Smith, and A. C. Whitmer. 2011. An integrated conceptual framework for long-term socialecological research. Frontiers in Ecology and the Environment 9:351-357. http://dx.doi.org/10.1890/100068

D'Herbès, J.-M., J. M. K. Ambouta, and R. Peltier, editors. 1997. Fonctionnement et gestion des écosystèmes forestiers contractés sahéliens. J. Libbey Eurotext, Paris.

Ehrlich, P., and A. Ehrlich. 1981. Extinction: the causes and consequences of the disappearance of species. Random House, New York, USA.

Elbow, K., and A. Rochegude. 1990. A layperson's guide to the forest codes of Mali, Niger, and Senegal. Land Tenure Center, Madison.
Fairhead, J., and M. Leach. 1995. False forest history, complicit social analysis. Rethinking some West African environmental narratives World Development 23:1023-1035. http://dx.doi.org/http://dx.doi.org/10.1016/0305-750X(95)00026-9

Fernandez, S., G. Bouleau, and S. Treyer. 2011. Reconsidérer la prospective de l'eau en Europe dans ses dimensions politiques. Développement durable et territoires 2:21.

Foley, G., W. Floor, G. Madon, E. M. Lawali, P. Montagne, and K. Tounao. 1997. The Niger household energy project. Promoting rural fuelwood markets and village management of natural woodlands. World Bank, Washington, D.C., USA. http://dx.doi.org/10.1596/0-8213-3918-4

Gallopín, G. C. 2006. Linkages between vulnerability, resilience, and adaptive capacity. Global Environmental Change 16:293-303. http://dx.doi.org/10.1016/j.

gloenvcha.2006.02.004

Galtier, F., F. Bousquet, M. Antona, and P. Bommel. 2012. Markets as communication systems. Simulating and assessing the performance of market networks. Journal of Evolutionary Economics 22:161-201. http://dx.doi.org/10.1007/s00191-011-0225-5

Garcia-Fernandez, C., M. Ruiz-Pérez, and S. Wunder. 2008. Is multiple-use forest management widely implementable in the tropics? Forest Ecology and Management 256:1468-1476. http://dx.doi.org/http://dx.doi.org/10.1016/j.foreco.2008.04.029

Gautier, D., T. A. Benjaminsen, L. Gazull, and M. Antonal. 2012. Neoliberal forest reform in Mali: adverse effects of a World Bank 'success'. Society \& Natural Resources 1-15.

Gautier, D., B. Hautdidier, and L. Gazull. 2011. Woodcutting and territorial claims in Mali. Geoforum 42:28-39. http://dx. doi.org/10.1016/j.geoforum.2010.08.008

Groupement Seed-CTFT. 1991. Schéma directeur

d'approvisionnement en bois énergie de Niamey: projet énergie II-Energie domestique. Volet offre. Document technique et de recherche, s.n., S.l..

Groupement Seed-CTFT. 1994. Les marchés ruraux du bois de feu au Niger et l'autogestion locale des ressources naturelles. La problématique et les leçons actuelles de l'expérience., République du Niger. Projet Energie IIEnergie domestique, Volet offre.

Guariguata, M. R., P. Sist, and R. Nasi. 2012. Multiple use management of tropical production forests: How can we move from concept to reality? Forest Ecology and Management 263:170-174. http://dx.doi.org/http://dx.doi.org/10.1016/j. foreco.2011.09.032

Haberl, H., V. Winiwarter, K. Andersson, R. U. Ayres, C. Boone, A. Castillo, G. Cunfer, M. Fischer-Kowalski, W. R. Freudenburg, E. Furman, R. Kaufmann, F. Krausmann, E. Langthaler, H. Lotze-Campen, M. Mirtl, C. L. Redman, A. 
Reenberg, A. Wardell, B. Warr, and H. Zechmeister 2006. From LTER to LTSER: conceptualizing the socioeconomic dimension of long-term socioecological research. Ecology and Society 11(2): 13. [online] URL: http://www.ecologyandsociety. org/vol11/iss2/art13/

Hautdidier, B. 2008. Bûcherons et dynamiques institutionnelles locales au Mali: La gouvernance incertaine des ressources ligneuses des environs de Bamako, à travers l'étude des marchés ruraux de bois de la commune de Zan Coulibaly. AgroParisTech.

Ichaou, A., and J. M. D'Herbès. 1997. Productivité comparée des formations structurées et non structurées dans le Sahel nigérien. Pages 119-130 in J. M. D'Herbès, J. M. K. Ambouta, and R. Peltier, editors. Fonctionnement et gestion des écosystèmes forestiers conttractés sahéliens. John Libbey Eurotext, Paris, France.

Kingdon, J. W. 2003. Agendas, alternatives and public policies. Longman Addison-Wesley Educational Publishers Inc. http://dx.doi.org/10.3886/ICPSR28024.v1

Larson, A. M. 2005. Democratic decentralization in the forestry sector: lessons learned from Africa, Asia and Latin America. Earthscan, London, UK.

Madon, G., and M. Matly. 1986. Conservation et substitution de l'énergie à usage domestique. Projet UNSO/NER/85/X02. SEMA-énergie.

Mahamane, L. E., and P. Montagne. 1997. Les grands axes stratégiques du Projet Energie II. Volet offre pour une gestion rationnelle des écosystèmes forestiers péri-urbains au Niger. Pages 155-167 in J. M. D'Herbès, J. M. K. Ambouta, and R. Peltier, editors. Fonctionnement et gestion des écosystèmes forestiers contractés sahéliens J Libbey Eurotext, Paris, France.

Mamoudou, H. 1991. Secteur économie-bois au Niger. Direction de l'environnement, Projet Energie II, Niamey.

Millennium Ecosystem Assessment. 2003. Ecosystems and human well-being: a framework for assessment. Washington, D.C., USA.

Miller, F., H. Osbahr, E. Boyd, F. Thomalla, S. Bharwani, G. Ziervogel, B. Walker, J. Birkmann, S. Van der Leeuw, J. Rockström, J. Hinkel, T. Downing, C. Folke, and D. Nelson 2010. Resilience and vulnerability: complementary or conflicting concepts?. Ecology and Society 15(3): 11. [online] URL: http://www.ecologyandsociety.org/vol15/iss3/art11/

Montagne, P. 1997. Les marchés ruraux de bois-énergie: outils de développement rural local. Page 2 p. in J. M. D'Herbès, J. M. K. Ambouta, and R. Peltier, editors. Fonctionnement et gestion des écosystèmes forestiers contractés sahéliens. J. Libbey Eurotext, Paris, France.
Montagne, P., and A. Bertrand. 2006. Histoire des politiques forestières au Niger, au Mali et à Madagascar. Pages 54-83 in A. Bertrand, P. Montagne, and A. Karsenty, editors. L'état et la gestion locale durable des forêts en Afrique francophone et à Madagascar. L'Harmattan, Paris, France.

Montagne, P., M. Housseini, and L. O. Sanda. 1997. Les marchés ruraux de bois-énergie au Niger: le mode de développement. Pages 169-184 in J. M. D'Herbès, J. M. K. Ambouta, and R. Peltier, editors. Fonctionnement et gestion des écosystèmes forestiers contractés sahéliens. J. Libbey Eurotext, Paris, France.

Nelson, F., editor. 2010. Community rights, conservation and contested land: the politics of natural resource governance in Africa. Earthscan Publications, Londres.

Ostrom, E. 2009. A general framework for analyzing sustainability of social-ecological systems. Science 325:419422. http://dx.doi.org/10.1126/science.1172133

Peterson, M. J., D. M. Hall, A. M. Feldpausch-Parker, and T. R. Peterson. 2009. Obscuring ecosystem function with application of the ecosystem services concept. Conservation Biology 24(1):113-119.

Petit, S. 2000. Environnement, conduite des troupeaux et usage de l'arbre chez les agropasteurs peuls de l'Ouest burkinabé. Approche comparative et systématique de trois situations: Barani, Kourouma, Ouangolodougou. Sécheresse 11.

Raynaut, C. 2001. Societies and nature in the Sahel: ecological diversity and social dynamics. Global Environmental Change 11:9-18. http://dx.doi.org/10.1016/S0959-3780(00)00041-8

Raynaut, C., E. Grégoire, P. Janin, J. Koechlin, and P. LavigneDelville. 1997. Sahels. Diversité et dynamiques des relations sociétés-nature. Karthala, Paris, France.

Renaud, F., J. Birkmann, M. Damm, and G. Gallopín. 2010. Understanding multiple thresholds of coupled socialecological systems exposed to natural hazards as external shocks. Natural Hazards 55:749-763. http://dx.doi. org/10.1007/s11069-010-9505-X

République du Niger. 1974. Loi n ${ }^{\circ} 74-7$ du 4 mars 1974 fixant le régime forestier. Page 10 1974-7, Niamey.

République du Niger. 1992. Ordonnance n ${ }^{\circ} 92-037$ du 21 août 1992 , portant organisation de la commercialisation et du transport de bois dans les grandes agglomérations, et la fiscalité qui lui est applicable. Page 10 92-037, Niamey.

Ribot, J. 1999a. Decentralization, participation and accountability in Sahelian forestry: legal instruments of political-administrative control. Africa 69.

Ribot, J. 1999b. A history of fear: imagining deforestation in the West African dryland forests. Global Ecology \& 
Biogeography 8:291-300. http://dx.doi.org/http://dx.doi. org/10.1046/j.1365-2699.1999.00146.x

Ribot, J. 2001. Science, use rights and exclusion: a history of forestry in francophone West Africa. IIED, Senegal.

Ribot, J. C. 1998. Theorizing access: forest profits along Senegal's charcoal commodity chain. Development and Change 29:307-341. http://dx.doi.org/10.1111/1467-7660.00080

Ribot, J. C., A. Agrawal, and A. M. Larson. 2006. Recentralizing while decentralizing: how national governments reappropriate forest resources. World Development 34:18641886. http://dx.doi.org/10.1016/j.worlddev.2005.11.020

Rives, F., R. Peltier, and P. Montagne. 2012. Fifteen years of forest community management in Niger: from a technician's dream to social reality. Small-Scale Forestry:1-19. http://dx. doi.org/10.1007/s11842-012-9203-5

Sabatier, P. A. 2007. The need for better theories. Pages 3-17 in P. A. Sabatier, editor. Theories of the policy process. Westview Press, Boulder, Colorado, USA.

Tacconi, L. 2007. Decentralization, forests and livelihoods: theory and narrative. Global Environmental Change 17:338348. http://dx.doi.org/10.1016/j.gloenvcha.2007.01.002

Tschakert, P. 2007. Views from the vulnerable: understanding climatic and other stressors in the Sahel. Global Environmental Change 17:381-396. http://dx.doi.org/10.1016/ j.gloenvcha.2006.11.008

Turner II, B. L., R. Kasperson, P. A. Matson, J. J. McCarthy, R. W. Corell, L. Christensen, N. Eckley, J. X. Kasperson, A. Luers, M. L. Martello, C. Polsky, A. Pulsipher, and A. Schiller. 2003. A framework for vulnerability analysis in sustainability science. PNAS 100:8074-8079. http://dx.doi.org/10.1073/ pnas. 1231335100

Walker, B., and D. Salt. 2006. Resilience thinking. Sustaining ecosystems and people in a changing world. Island Press, Washington, D.C., USA.

World Bank and United Nations Development Programme. 1989. Senegal: urban household energy strategy. Energy Sector Management Assistance Program: 67. Washington, D. C., USA.

${ }^{[1]} 1 \mathrm{CFA} F=€ 0.15245$ (exchange rate in 2011)

${ }^{[2]}$ The way this negotiation occurred and the changes involved in wood income sharing are not the purpose of our paper. They have been studied by other authors (Ribot 1998, Antona et al. 2002).

${ }^{[3]}$ These data were recorded in the ledger only up to 2000 . The data for 2009 were given by the LSM managers. 
APPENDIX 1: SES functions in Ñinpelima

Table A1.1: List of SES functions identified in Ninpelima and their respective products

\begin{tabular}{ll}
\hline \hline Functions & Function products \\
\hline Farm production & Food for livelihood or income \\
Livestock production & Zebu, Cheep, Goat \\
Timber provision & Wood processed to make furniture and ustensils \\
Lumber provision & Raw wood for house and pen building \\
Urban firewood provision & 1m-long Stems for urban household fuelwood \\
Rural firewood provision & Stems and crowns for rural household fuelwood \\
Edible leaf provision & Fresh or dried leaves for human consumption \\
Construction fiber provision & Vegetal fibers processed for house building \\
Basket-making fiber provision & Vegetal fibers processes for basket-making \\
Edible fruit provision & Wild or crop fruits for human consumption \\
Gum provision & Gum for feeding or for textile and food industry \\
Honey provision & Wild honey \\
Medicine provision & Traditional herbs \\
Bush meat provision & Meat from hunted wild animals \\
Soil protection & Soil intentionally protected against water and wind erosion \\
Soil fertility renewal & Soil where fertilization have been intentionally improved \\
\hline
\end{tabular}


APPENDIX 2 : Situation of Ninpelima RM among Torodi’s RMs

According to the studies conducted in the Household Energy Project, the rural council of Torodi supplied more than 40\% of Niamey firewood (Groupement Seed - CTFT 1991). Among the 62 rural markets (RMs) of Torodi, 18 supply $70 \%$ of the firewood going to Niamey (Fig A2.1). Kankani, Mossipaga, Niaktiré and Ninpelima are among the first RMs created in Niger. RM ledgers have only been properly completed in Ñinpelima and Kankani since their establishment. Some irregularities excepted, taxes have been routinely collected in these RMs.

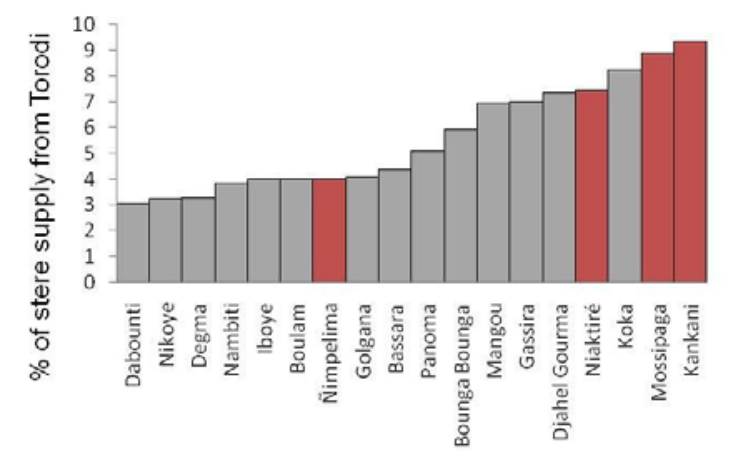

Figure A2.1: Part of firewood supplied by the 18 most productive RMs (Source: traffic survey, Gesforcom project)

Ñinpelima RM is located at moderate distance from Niamey, and thus, forest resources have not been overexploited as this is the case in the areas surrounding Niamey. Nevertheless, the $\mathrm{RM}$ is active, unlike some distant RMs which are practically inaccessible to wood traders. 
APPENDIX 3: Importance of SES functions for the villagers of Ñinpelima

The villagers differentially participate to several functions. Figure A3.1 and A3.2 illustrate the ranking of SES functions according to their importance in the villagers' income. This ranking is very different between women and men and between Gourmantche and Fulbe people.

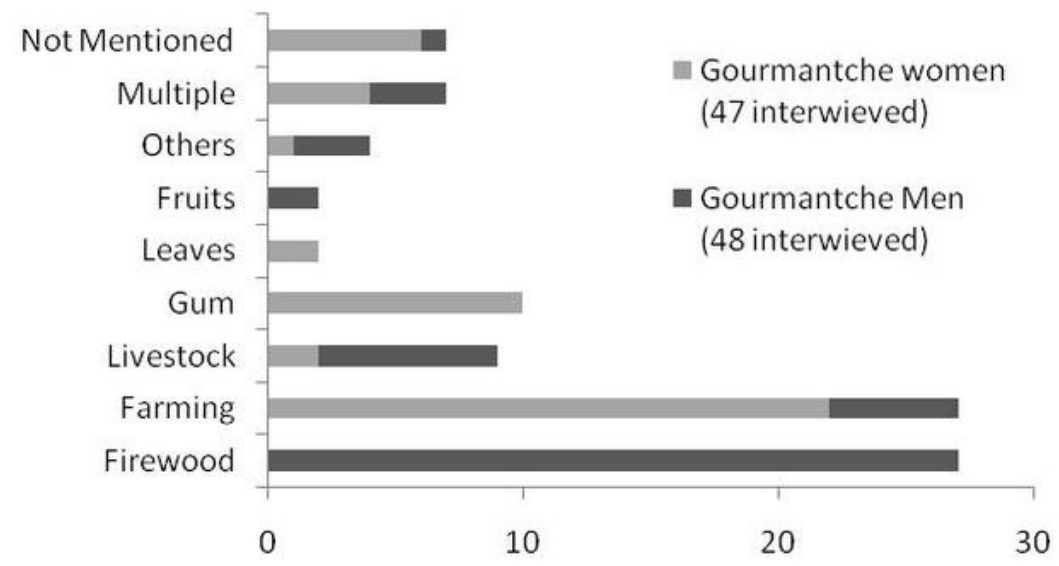

Fig A3.1: The interviewed Gourmantches ranked SES functions according to their importance in their incomes.

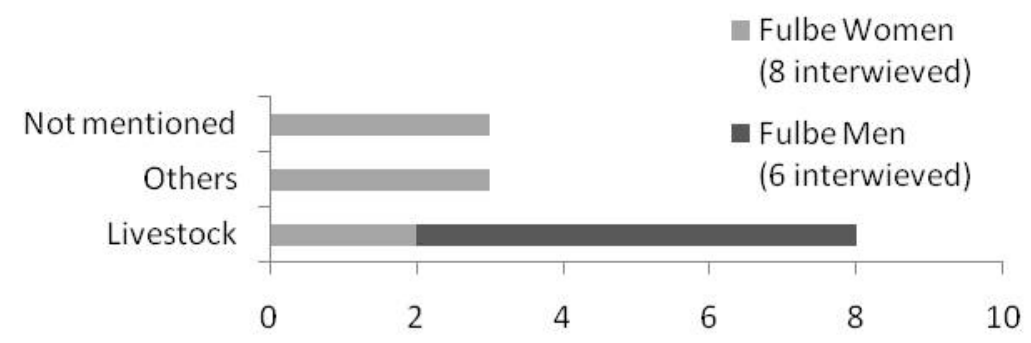

Fig A3.2: The interviewed Fulbes ranked SES functions according to their importance in their incomes. 